\title{
SEPARATION EVENTS IN TAFI LANGUAGE AND CULTURE
}

\author{
Mercy Bobuafor \\ University of Ghana
}

\begin{abstract}
Separation events differ in lexicalisation patterns (Talmy 2000) and in argument realisation (Levin and Rappaport Hovav 2005) cross-linguistically. There are different types of separation events. "Cutting" and "breaking" events involve a non-reversible change in object integrity and have been systematically researched cross-linguistically in recent times (Guerssel et al 1985; Bohnemeyer 2008; Majid et al. 2008; Schaefer and Egbokhare 2012). In this paper, some of the generalisations that have been made concerning CUT and BREAK verbs are tested based on data from Tafi, a Ghana-Togo Mountain language. I investigate the morpho-syntactic properties of Tafi CUT and BREAK verbs in relation to a suggested generalisation by Guerssel et al. that BREAK verbs have a transitive/intransitive argument structure and participate in the causative/inchoative alternation; while CUT verbs are transitive and they are not expected to occur without their external argument. The types of events referred to by the CUT and BREAK verbs and the combinatorial capacity of the individual verbs are also explored. Based on an analysis of stimulus-elicitations and spontaneous language performances recorded in the field, I show that the Tafi verb bhui 'cut' can be used in an intransitive/resultative construction in which the theme, the internal argument, occurs as the subject. Drawing on the behaviour of bhui 'cut' I interrogate the explanations that have been offered in the literature with respect to such deviations from the generalisation. I argue that the verb argument alternation potential of a verb depends on the verb semantics as well as the type of (internal) argument it collocates with. Moreover, I explore the semantic interpretations of the verb when it combines with non-typical objects such as 'water'. I show that such patterns and collocations such as 'the water cut' $=$ 'the water stopped running', 'cut a village' = 'establish a village' are areal in nature (cf. Huttar et al. 2007).
\end{abstract}

Keywords: CUT and BREAK verbs, inchoative alternation, lexicalization, Tafi, Ewe, collocations

\section{Introduction}

Languages differ in the way the conceptual category of separation is coded. Previous studies have focused on two types of separation events involving a destruction in the material integrity of entities - 'cutting' and 'breaking' events. The linguistic expressions that code these separation events differ in their lexicalization patterns (Talmy 2000). Thus it has been shown that languages like K'iche and Mayan languages generally (Pye 1996, Brown 2007) do not have general CUT and BREAK verbs, rather they have specific verbs to describe specific types of separation events, e.g. K'iche' has specific BREAK verbs like joyopi:j 'break a banana from a bunch of bananas' and jockopi:j 'break a banana by failing to support the whole bunch'. Ameka and Essegbey (2007) have also shown that Ewe (Gbe), a Kwa language which is the dominant lingua franca in the Tafi speaking area, does not have a general BREAK verb, rather it has two verbs for describing breaking events. The distinction between the verbs depends on the type of object that is affected, 
the theme: $g b a$ 'break smash' and yé 'fulcrum break of brittle and long things'. It will be shown that Tafi also does not have a general BREAK verb but two verbs distinguished along similar lines as in Ewe.

CUT and BREAK verbs also differ in their argument realization patterns crosslinguistically (Levin and Rappaport 2005). This follows from a seminal morphosyntactic generalization that was made about these verbs by Guerssel et al. (1985). Based on investigations of transitivity alternations in four genetically and typologically diverse languages, Warlpiri, Berber, English and Garifuna, Guerssel et al. found a commonality, namely, that BREAK verbs undergo causative/inchoative alternation, that is a transitive/intransitive alternation. Compare the English sentences John broke the glass; and The glass broke. CUT verbs, on the other hand, occur only in transitive clauses and in English participate in a conative alternation as well: E.g. Mary cut the rope vs. *The rope cut vs. Mary cut at the rope. The difference between the two classes of verbs is attributed to a difference in their lexical conceptual structure or semantics. Thus, CUT verbs do not participate in the inchoative alternation because they entail instruments. BREAK verbs, on the other hand, participate in the alternation as they do not entail such argument roles. Studies of these verbs in other languages such as the Kwa languages, Ewe and Akan, indicate that there is, first, an overlap between events that are described using CUT and BREAK verbs (cf. Naess 2012). Second, it is shown that some CUT verbs participate in the transitive/intransitive alternation under certain conditions (Ameka and Essegbey 2007). Attempts have been made to account for these observed facts (see e.g. Bohnemeyer 2007). Concerning the overlap between the CUT and BREAK verbs in terms of transitivity, Ameka and Essegbey (2007) suggest that the verbs seem to differ in their agentivity. They propose that the verbs could be plotted on a scale of agentivity:

$$
\text { highly agentive - agentive - non-agentive - highly non-agentive }
$$

The verbs that occur at the extreme ends of the scale, i.e., highly agentive and highly non-agentive exhibit the morphosyntactic properties of CUT and BREAK verbs respectively, as identified by Guerssel et al. (1985) noted above. In between the extreme ends are two other points and this is the area where there is overlap between the verbs: The agentive verbs are those which may lexicalize an instrument role and can participate in the causative/inchoative alternation under certain circumstances, namely, when the separation event described does not involve an instrument in its realization. Ameka and Essegbey (2007) argue that the Ewe verb tso 'cut' is one of these agentive verbs. I also argue that the Tafi verb bhui 'cut' behaves like this. When these verbs are used to describe events which require an instrument they do not participate in the transitive/intransitive alternation. However, when they are used to describe situations involving certain themes e.g. liquids or flexible objects, for which an instrument may not be required to effect a separation, they can occur in intransitive constructions. Non-agentive verbs describe type of separation but do not incorporate an instrument. Like the agentive verbs they do not participate in the causative/inchoative alternation when an instrument is required to effect the separation. The Tafi verbs $p$ ' 'snap off' and tsywĩ 'tear' behave like this.

Broadly speaking, the highly agentive and the agentive verbs are the CUT verbs of Guerssel et al. While the non-agentive and highly agentive ones are the BREAK verbs. It will become evident that it is the agentive CUT verbs like Tafi bhui 'cut' that have deviant behavior from the generalization put forward by Guerssel et al. 1985. Curiously, equivalents of these verbs across Kwa languages display similar behavior. Given the parallels in behavior, collocations and 
interpretations in other domains such as EAT and DRINK (cf. Welmers 1973) or BELIEVE and BEGIN (cf. Ameka 2006), I explore whether collocations involving the primary agentive CUT verbs and their interpretations in Tafi, Ewe, Akan and Ga are similar or different. I also ask the question whether the similarities can be explained by contact.

The aim of this paper is to examine the syntax and semantics of separation verbs, i.e., CUT and BREAK verbs in Tafi, a Ghana-Togo-Mountain (GTM) language. Second, it explores the collocations and interpretations of the agentive CUT verb bhui in Tafi comparing them to similar verbs in other Kwa languages. The goal is to see the extent to which collocations involving nontypical objects such as 'the water cut' and 'cut a village', or 'the river cut', i.e., the river has dried up, and 'I cut', i.e., 'I have finished speaking, I am done' can be attributed to areal semantic patterns, or language- and culture-specific motivations.

The data for this paper was obtained during immersion field investigations in Tafi Mado (in the southeastern part of Ghana) using various methods: elicitation based on the video stimuli of "cut" and "break" video clips (Majid et al. 2007), ${ }^{1}$ natural language use discourse about separation events, and observed linguistic practices.

The elicitation with the video stimuli is carried out by showing the video clip to consultants. In the event where an actor acts on an object and it results in a break/cut, consultants are asked what the actor did to the object. After that, they are asked what happened to the object. In the discussion, I use the word "separate" and its derivations such as "separating", "separation" etc., as neutral terms to represent the event of cutting and breaking and they are not to be taken to mean complete separation.

The rest of the paper is organized as follows: in the next section, I provide a brief background to the investigation of separation events and this is followed by a typological profile of the Tafi language in section 2. The various CUT and BREAK verbs in Tafi are presented in section 3. In this section, I discuss the syntax, use and meaning of these verbs. Section 4 explores the semantic extensions and interpretations of the cut verb bhui in comparison to similar extensions of CUT verbs in Ewe, the lingua franca and two other Kwa languages, Akan and Ga. Section 5 concludes the paper.

\section{Background}

In terms of the lexicalization of separation events Guerssel et al. (1985), based on a study of genetically and typologically diverse languages, proposed that there are two classes of predicates: CUT and BREAK verbs. BREAK verbs participate in a causative/inchoative alternation, that is, a transitive-intransitive alternation as illustrated for English in (1). They do not entail the use of an instrument.

English

(1) a. Helen broke the pot.

b. The pot broke.

1 The stimuli material can be accessed from fieldmanuals.mpi.nl. The clips are further described in section 1. 
CUT verbs, on the other hand, entail instruments and do not participate in causative/inchoative alternation, i.e., they are not expected to occur without their external cause argument. Hence, they are expected not to occur intransitively. They, however, participate in the middle construction as in $(2 c)$.

English

(2) a. Helen cut the rope

b. *The rope cut

c. The rope cuts easily (Middle construction)

This difference in syntactic behaviour is a reflection of the differences in their semantics. This claim has been extended to all the verbs of change of state (Haspelmath 1993, Levin 1993 and Levin \& Rappaport Hovav 1995). According to them, the differences in the meaning of these verbs including verbs that encode only a result of change of state bring about differences in transitivity alternations. CUT verbs specify a particular causing event while BREAK verbs focus instead on the end result of a "cutting" or "breaking" action. CUT verbs have a transitive argument structure, they predicate an agent acting on a theme and focus on instrument or manner. They do not participate in the causative/inchoative alternation. The causative/inchoative alternation involves both the transitive and intransitive uses of a verb. The transitive sentence expresses an agent acting on a theme whereas its intransitive counterpart expresses the theme entering into a state. The transitive variant of the verb may be paraphrased as "cause to V-intransitive" (Levin 1993). Instead, "cut" verbs participate in middle constructions (e.g., the meat cuts easily), if one exists in the language. "Break" verbs predicate on a theme that undergoes a change of state and they focus on the resulting state. These verbs participate in the causative/inchoative alternation. The equivalent of "The rope cut" ( $2 b)$ is acceptable in many Ghanaian languages including Tafi. This behaviour requires explanation and this will be addressed in Section 4 (see Ameka and Essegbey 2007 on Ewe and Agyepong 2017 on Akan).

Another early study by Pye (1994) demonstrated that the equivalents of these verbs in many languages were applied to different objects and the extensions of a particular verb may cover different objects (see Fig. 1 below, and Majid et al. 2008).

Figure 1: Comparison of C\&B verbs in English, Garifuna, and Mandarin (Pye 1994)

\begin{tabular}{|l|c|c|c|c|}
\hline \multirow{2}{*}{} & & & & \\
& & & & \\
& cloth & bubble & plate & stick \\
\hline English & tear/rip & pop & \multicolumn{2}{|c|}{ break } \\
\hline Garifuna & teiriguana & \multicolumn{2}{|c|}{ bowguana } & halaguana \\
\hline Mandarin & \multicolumn{3}{|c|}{ non4-puo4 } \\
\hline
\end{tabular}


To test this and other hypotheses, Juergen Bohnemeyer, Melissa Bowerman, Penelope Brown and colleagues designed "cut" and "break" video clips at the Max-Planck Institute for Psycholinguistics in Nijmegen, the Netherlands. These are 61 short video clips showing a variety of events involving breaking, cutting and opening which occurred spontaneously or which were performed by actors either on different objects, with different instruments or in different manners (Majid et al. 2007). 48 clips involve people engaged in acts of cutting and breaking. The remaining 13 clips involve opening, shutting and peeling, which were meant to be distractors.

Majid et al. (2008) report on results of the investigation of these verbs in 30 languages. Some of the findings related to typological variation in the coding of cutting and breaking events and in the dimensions that guide speaker assignment of expressions. For instance, English codifies manner and change of state in one verb, while Chinese uses Verb-Verb compounds in which one verb codes manner and the second verb the result. It has been shown that in the Kwa languages (e.g. Ewe (Ameka and Essegbey 2007), and Tafi (Bobuafor 2013)) the type of action performed by an agent/effector that brings about a change in a patient is codified in a verb. A Serial Verb Construction (SVC) is used to code the manner plus result separation events.

In terms of the dimensions that guide the choice of one verb or the other for the description of events, Majid et al. (2008) noted that speakers seemed to be guided by the predictability of the locus of separation in an object that is acted upon. The predictability of the locus of the instrument for SLICE events was high as to slice an object, one needs to place the instrument in a specific place. For CHOP events the predictability was midway, less than for SLICE and more than for SMASH events. This follows from the fact that for CHOP events one does not have to be that precise about where to place the instrument before the separation. Also, for SMASH events the predictability is low as it can be effected by any type of action. The type of instrument used distinguished CUT events involving bladed instruments from BREAK events, involving instruments of a sharp blow, and also from events involving the use of hands or no artefactual instrument or blow, the TEAR events. SMASH events are distinguished in relation to the type of object acted upon: long rigid objects acted upon with a sharp blow are described as SNAP events.

I will show that from a lexical-typological point of view, Tafi behaves like other Kwa languages in using one verb to characterize highly agentive CUT events and one to characterize SLICE and CHOP events. This verb seems less agentive and does not therefore conform to the hypothesis about CUT verbs which are not supposed to undergo causative-inchoative alternation in all its uses. Tafi also uses one verb each to code SMASH-BREAK and SNAP-BREAK. One verb is used to code TEAR events as well. In addition, I also show that the lexical semantics of the 'cut' verb in Tafi is similar to that found in other Kwa languages like Ewe. Furthermore, the extended semantic readings of the verb in Tafi are also shared with some of the languages. However there are some readings that are only found in Tafi.

\section{Typological features of Tafi}

The Tafi language or Tigbo (tcd) is spoken in the South-eastern part of Ghana by about 4,400 people who call themselves Bagbo (Simons and Fennig 2017). It is spoken in four (4) communities, namely, Agome, Madə, Abuifé ${ }^{2}$ and Atome. South of the Tafi area live the Nyagbo people. To the east of Tafi are the Avatime and Logba people. The closely related Nyagbo people

2 The IPA symbol for ' $f$ ' is $/ \phi / .<f>$ is the orthographic representation. 
have together with Tafi, sometimes, been thought of as one group and there is some degree of mutual intelligibility between them (cf. Heine 1968).

Tafi, like all the other GTM languages, has an active system of noun classes in which each noun belongs to a particular class which is identified by prefixes and a system of concords. Thus, it marks singular/plural alternations with prefixes and often requires concord of other elements in the sentence with the governing noun. In this way, the subject NP determines what affix is used for agreement on the verb (see Bobuafor 2009, 2013).

Tafi has a nine vowel system. All these vowels except /o/ have nasalized counterparts. The vowels participate in a cross-height harmony. These vowels are divided into two (2) sets, /i, e, o, $\mathrm{u} /$ which are $[+\mathrm{ATR}]$ and $/ \mathrm{l}, \varepsilon, \mathrm{a}, \mathrm{\jmath}, \mathrm{v} /$ which are [-ATR] based on the position of the tongue root. Vowel harmony in Tafi is root-controlled, in the sense that the vowel of prefixes harmonizes with the vowel of the first syllable of the root. Thus, depending on the [ATR] value of the initial vowel in the root, the prefix may have varied forms. For instance, the [ATR] value of the vowels in the verb roots in the sentences in (3) determines the [ATR] value of the verbal prefixes below: ${ }^{3}$

(3) a. Abayo kápamín.

á-ba-yo ká-pamí ní

3SG-FUT-sharpen CM-cutlass DEF

'S/he will sharpen the cutlass.'

b. Ebeplǔ 'íd̄̄.

e-be-plǔ kí-d̄̄
3SG-FUT-wash
'S/he will wash.'

As shown in the examples above, the vowel in the verb in (3a) is [-ATR] so the vowels of the subject pronoun and future prefixes are also [-ATR] while the vowel in the verb in (3b) is [+ATR] and thus the vowels in the prefixes attached to this verb are also [+ATR] in value.

Tafi has three level tonemes: High (marked with an acute accent), Mid (marked with a macron) and Low (left unmarked or with a grave accent on syllabic nasals) plus Rising (R) and Falling (F) tones, marked with a hacek, and a circumflex respectively. These tones can be used to indicate lexical contrast as in (4) and they have inflectional functions as well, as shown in (5):

(4) kilé 'tooth' kilě 'lizard'

kımó 'breast' kımo 'rubber, gum'

(5) a. Bééplǔ 'íd̄.

$\begin{array}{ll}\text { bé-é-plǔ } & \text { kí-d̄̄ } \\ \text { 3PL-PRSPROG-wash } & \text { CM-thing }\end{array}$

'They are washing.'

3 Examples from Tafi are presented in four lines: the first one is a practical orthographic representation of the spoken form. The second line provides the morphological representation with underlying forms and the third line is the interlinear gloss while the fourth line is the idiomatic free translation. 
b. Béeplǔ 'íd̄̄.

$\begin{array}{ll}\text { bé-e-plǔ } & \text { kí-d̄̄ } \\ \text { 3PL-PSTPROG-wash } & \text { CM-thing }\end{array}$

'They were washing.'

The difference between (5a) and (5b) is that the present progressive and the past progressive aspects are indicated by a high and low tone respectively.

Tafi is a Subject-Verb-Object-Other (SVOX) language. In double-object constructions, the Goal precedes the Theme and in locative constructions, the Theme occurs as the first object while the Locative occurs as the second object. Also, adjuncts occur after the core arguments in the clause. Pragmatically salient constituents with topic and focus functions occur in the left-periphery of the clause (see Bobuafor 2013).

\section{Tafi separation verbs: an overview}

The verbs used to describe separation events, and which were used in response to the "cut" and "break" scenes depicted in the video clips fall into two morphosyntactic groups corresponding roughly to the CUT and BREAK verbs identified by Guerssel et al. (1985). Within each group, the verbs can be further distinguished on the basis of their agentivity based on Ameka and Essegbey's (2007) agentivity scale discussed in section 1. The BREAK verbs consist of the highly nonagentive $t$ sywĩ 'tear', $y \check{\varepsilon}$ 'smash, break', and dzyíni 'fulcrum-break' as well as the non-agentive $p$ ' 'snap-off'. The CUT verbs are the highly agentive tế 'slash', and the agentive bhui 'cut' and yá 'cut'. The agentive CUT verbs unlike the highly transitive CUT verb can participate in the causative/inchoative alternation when the separation events they represent do not require an instrument to be realized. The verbs are described in turn starting with the BREAK verbs.

3.1 The syntax of BREAK verbs. In Tafi, tsywĩ 'tear', y̌̌ 'break, smash', dzyínī 'fulcrumbreak', and $p \mathfrak{s}$ 'snap off' participate in the causative/inchoative alternation. These verbs are used in transitive constructions when they have a causal meaning and the causal agents have to be expressed. For instance, the following sentences in (6a-c) were used to describe events in which someone tears a piece of cloth (clip 1), breaks a stick into pieces over his knee (clip 5) and cuts a rope (clip 2). Tsywĩ 'tear', dzyínī 'fulcrum-break', and pó 'snap off' are illustrated in sentences (6a) and (6c) respectively.

(6) a. Ádzınúvōēń átsywĩ kepútakpá.

\begin{tabular}{|c|c|c|}
\hline a-dzınơvō̄̄ ní & á-tsywĩ & ke-pútakpá \\
\hline CM-girl & SM-tear & CM-piece.of.cloth \\
\hline
\end{tabular}

b. Ányínơvōēń édzyínī kishǐním̄ bhulí bhulí.

$\begin{array}{lllllll}\text { á-nyínóvō̄̄ ní } & \text { é-dzyínī } & \text { ki-shǐ } & \text { ní } & \text { kımı } & \text { bhulí bhulí } \\ \text { CM-boy DEF } & \text { SM-break } & \text { CM-stick } & \text { DEF } & \text { inside } & \text { small-small } \\ \text { 'The boy broke the stick into pieces.' (clip 5) } & & \end{array}$


c. Ányínưvōēń ápó ohuiń.

$\begin{array}{llll}\text { á-nyínóvō̄e ní } & \text { á-pó } & \text { o-hui } & \text { ní } \\ \text { CM-boy DEF } & \text { SM-snap } & \text { CM-rope } & \text { DEF } \\ \text { 'The boy snapped the rope.' (clip 2) }\end{array}$

In response to what happened to the cloth in (6a), the stick in (6b) and the rope in (6c), consultants gave the following responses in $(7 \mathrm{a}-\mathrm{c})$ which involve the intransitive use of these verbs:

(7) a. Kepútakpáń 'átsywĩ.

ke-pútakpá ní ká-tsywĩ
CM-piece.of.cloth DEF SM-tear
'The piece of cloth tore / is torn.' (clip 8 cloth tear)

b. Kishǐń 'ídzyínī.
ki-shǐ ní ki-dzyínī
CM-stick DEF SM-break
'The stick broke / is broken.' (clip 16 stick break)

c. Ohuin opó.
o-hui ní o-pó
CM-rope DEF SM-snap
'The rope snapped off.' (clip 46 rope_cut)

Some consultants also used the same sentences in (7a-c) to describe the spontaneous tearing of a cloth (clip 8), snapping off of a rope (clip 46) and the breaking of a twig (clip 16) while others gave the sentences in (8a-c) as a description of these spontaneous events. This shows that the verbs can be used to describe spontaneous happenings which do not involve a causer or an agent. It means that the verbs do not entail an agent in their semantic specification.

(8) a. Kepútakpán 'atsywĩ ní 'alí shú áhər.

$\begin{array}{llllllr}\text { ke-pútakpá } & \text { ní } & \text { ka-tsywi } & \text { ní } & \text { kalí } & \text { shú } & \text { a-həı } \\ \text { CM-piece.of.cloth } & \text { DEF } & \text { SM-tear } & \text { LOC } & \text { 3SG.IND } & \text { body } & \text { CM-hand } \\ \text { 'The piece of cloth tore on its own / by itself.' } & & & \end{array}$

b. Ohuin opó n'ólí shú áhot.

\begin{tabular}{|c|c|c|c|c|c|}
\hline o-hui & o-pj́ & ní & olí & shú & a-həı \\
\hline CM-rope DEF & SM-snap & LOC & 3SG.IND & body & CM-hand \\
\hline
\end{tabular}

c. Kishǐn ídzyínī n'illí shú áhø.
ki-shǐ ní kí-dzyínī ní clí shú a-hoı
CM-stick DEF SM-break LOC 3SG.IND body CM-hand
'The stick broke on its own / by itself.' 
The meanings of the sentences in (6) are different from those in (7) in the sense that the verbs in (6) encode a notion of cause while those in (7) simply denote a process in which the patient undergoes a change of state without specifying how the change of state comes about. The sentences in (8), on their part, specify how the change of state in those objects happened, and that is, the change came about spontaneously.

Since these verbs do not lexicalize instrument, a take-Serial Verb Construction (SVC) as in (9a) or an adverbial phrase as in (9b) can be used to show that a type of instrument was used. The sentences in (9) were given as a description of an event in which a hammer was used to smash a carrot (clip 21).

(9) a. Ányín áyíko hámāń áyč károtīním.

$\begin{array}{llllllll}\text { á-nyí ní } & \text { á-yíks } & \text { hámā } & \text { ní } & \text { á-y̌̃ } & \text { károtī } & \text { ní } & \text { kımı } \\ \text { CM-man DEF } & \text { SM-take } & \text { hammer } & \text { DEF } & \text { SM-smash carrot } & \text { DEF } & \text { inside } \\ \text { 'The man used the hammer to smash the carrot.' (clip 21, break carrot hammer) }\end{array}$

b. Ányín áyč károtī nı hámā.

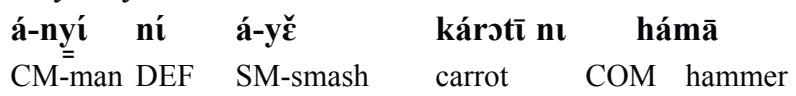

'The man smashed a carrot with a hammer.'

The verbs occur in transitive and intransitive constructions as well as in the take-SVC. This distribution confirms and provides evidence that the Tafi verbs do not lexicalize instruments. If instruments are involved in the realization of the situation they are expressed using grammatical constructions that make them explicit - a comitative prepositional construction or an SVC.

\subsection{The use and meanings of the TEAR and BREAK verbs.}

3.2.1 Tsywi 'tear'. Tsywĩ 'tear' focuses on the nature of change that an object undergoes. It is used to describe events which depict the tearing of flexible objects like fabrics and paper. For instance, in the video clips, it was used to describe an actor tearing a piece of cloth (clip 1) and a piece of cloth tearing spontaneously (clip 8) (see examples 6a and 7a above).

3.2.2 Y̌̌ 'break, smash'. Tafi makes a distinction between smashing a rigid object such as a pot, glass or a plate with a sharp blow and snapping a long object like a stick or carrot in two pieces. A similar distinction is made in Ewe and related languages (see Ameka \& Essegbey 2007). $Y \check{\varepsilon}$ 'break, smash' encodes information about the result state of the patient. It is used to describe the breaking and shattering of objects such as plates, pots, and bottles. During the elicitation, $y \check{\varepsilon}$ 'break, smash' was used to describe events in which an actor breaks a plate (clip 40) and a pot (clip 39) as shown in example (10a). It was also used to describe the smashing of a carrot and a stick into several fragments (clips 21 and 31) (see example (9) above). Like gba 'break' in Ewe, the focus of the verb $y \check{\varepsilon}$ 'break, smash' is on the cracks that get introduced into the patient. However, for an event to be described as a $y \check{\varepsilon}$-event, the broken pieces must be fully separated. In the situation where the broken pieces do not come apart, the verb tá 'crack' is used as illustrated in (10b). 
(10) a. Ádzınúvōēń áyč kitsikpǐn ní hámā.

$\begin{array}{lllllll}\text { a-dzınóvōé } & \text { ní } & \text { á-y̌̌ } & \text { ki-tsikpì } & \text { ní } & \text { ní } & \text { hámā } \\ \text { CM-girl } & \text { DEF } & \text { SM-break } & \text { CM-pot } & \text { DEF } & \text { COM } & \text { hammer } \\ \text { 'The girl broke the pot with a hammer.' (clip 39) } & & \end{array}$

b. Kitsikp̌rń 'ítá.

ki-tsikpǐ ní kí-tá
CM-pot DEF SM-crack
'The pot has cracked.'

As shown above in examples (9) and (10a), the verb $y \check{\varepsilon}$ 'break, smash' does not lexicalize an instrument, and if an instrument is involved in the realization of the event then this is introduced in the linguistic expression through SVCs and adjunct phrases. Furthermore, separation events described by this verb need not involve an agent. The descriptions can focus on the result state. As such the verb participates in the causative/inchoative alternation.

3.2.3 Dzyínī 'fulcrum-break'. Dzyínī 'fulcrum-break', like y̌̌ 'break', also encodes information about the patient, and its result state. It is used to describe events in which an object that is hard and long snaps along the fulcrum. This event may or may not be caused by the application of some kind of pressure. For instance, dzyini 'fulcrum-break' was used to describe an event which involves someone breaking a stick across the knee (clip 5) (as in example 6b above repeated here as (11)). The fracture caused by the breaking event need not be complete as this verb was used to describe the snapping of a twig which broke completely (clip 19) or which still remained connected by a few strands (clip 25) as illustrated in (11b). Dzyíni 'fulcrum-break' is used to describe the breaking of objects like sticks and bones in a finger, a hand or a leg.

(11) a. Ányínúvōēń édzyín̄̄ kishǐním bhulí bhulí.

$\begin{array}{llllll}\text { á-nyínúvōe ní } & \text { é-dzyínī } & \text { ki-shǐ } & \text { ní } & \text { kımı } & \text { bhulí bhulí } \\ \text { CM-boy DEF } & \text { SM-break } & \text { CM-stick } & \text { DEF } & \text { inside } & \text { small-small } \\ \text { 'The boy broke the stick into pieces.' } & & & \end{array}$

b. Ányínưvōēń édzyínī kishǐním po kıdısókī .

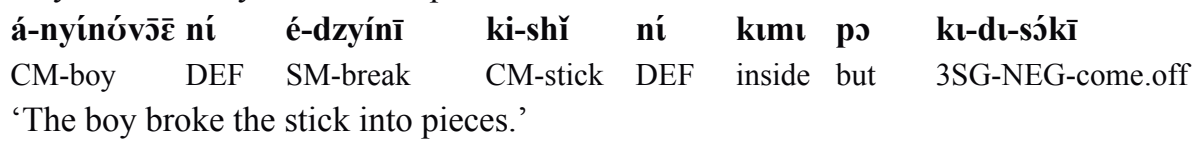

Like the break-smash verb, this fulcrum-break verb participates in the causative/inchoative alternation showing that it does not entail an agent in its lexicalization.

3.2.4 Pá 'snap off'.Pó 'snap off' is a general separation verb which primarily entails complete severance of the parts of the object. It is a non-agentive verb which is used to describe events involving separation without specifying the instrument or manner (Ameka \& Essegbey 2007). Thus, in the video clips, $p$ ś 'snap off' was used to describe a series of events in which a rope stretched between two tables was snapped with a single downward blow of a chisel (clip 2), in which a piece of yarn was broken into many pieces (clip 35). It was also used to describe events in 
which a yarn was pulled and a piece broken off it (clip 38) and in which a rope snaps spontaneously (clip 46). Thus it can be used intransitively as in (12d). If the manner or instrument used to perform a ṕ-event needs to be specified this is done by using a take-serial verb construction as in (12b) or a comitative prepositional phrase as illustrated in (12c) in which a chisel was used in snapping a rope:

(12) a. Ápó ohuiń.

á-pó o-hui ní

3SG-snap CM-rope DEF

'He snapped the rope.'

b. Áyíko odéćshǐń ópó ohuiń.

á-yíks o-déćshǐ ní ó-pó o-hui ní

3SG-take CM-metal.stick DEF SM-snap CM-rope DEF

'He used a chisel to snap the rope.'

c. Ápó ohuiń n'odéćshǐ.

$\begin{array}{lllll}\text { á-pó } & \text { o-hui } & \text { ní } & \text { nı } & \text { o-déćshǐ } \\ \text { 3SG-snapCM-rope } & \text { DEF } & \text { COM } & \text { CM-metal.stick }\end{array}$

'He snapped the rope with a chisel.'

d. Ohuin opó n'ólí shú áhət.

\begin{tabular}{|c|c|c|c|c|c|}
\hline o-hui & o-pj́ & ní & olí & shú & a-həı \\
\hline CM-rope DEF & SM-snap & LOC & 3SG.IND & body & CM-hand \\
\hline
\end{tabular}

'The rope snapped off on its own/ by itself.'

In sum, the BREAK verbs are non-agentive to various degrees as noted above and do not entail agents. When an agent is involved in the realization of the event, it has to be expressed. Similarly the verbs do not incorporate an instrument. When an instrument is used in the realization of the event it is expressed as the theme object in a take-SVC or as the complement of the comitative/instrumental preposition.

3.3 The CUT verbs. CUT verbs in Tafi include tế 'slash', bhui 'cut' and yá 'cut'. Following the hypothesis of Guerssel et al. (1985) and others, one would expect all three CUT verbs not to participate in the causative/inchoative alternation. As will become clear below however, the verbs differ in their agentivity leading to some of them, specifically, bhui and yá, participating in this alternation. This is a situation that occurs in the other languages in the area, where less agentive CUT verbs do not support the hypothesis.

As argued in Bobuafor (2013), the verbs of cutting are used to describe separation events involving an agent acting on a patient that brings about a change in the material integrity of a patient and they focus on instrument or manner. I discuss each of the verbs in turn.

3.3.1 Tế 'slash'. Tế 'slash' is a highly agentive verb in the sense that it cannot occur without an agent performing the action expressed by the verb (see Bobuafor 2008 on Tafi and Ameka \& Essegbey 2007 on Ewe). It does not therefore occur in an intransitive construction, as the 
unacceptability of sentence (13b) below shows. The verb tế 'slash' lexicalizes a specific manner and/or instrument. It is used to describe cutting events which are done in a slashing manner. Such events entail the use of prototypical instruments like axes, machetes and big knives which are heavy by nature and need to be sharp for use.

(13) a. Ányín étế os'óshě̃̆n (n'lápamí).

$\begin{array}{llllllll}\text { á-nyí } & \text { ní } & \text { é-tẽ̃ } & \text { o-sí } & \text { ó-sh } \check{\tilde{\varepsilon}} & \text { ní } & \text { (nı } & \text { ká-pamí) } \\ \text { CM-man } & \text { DEF } & \text { SM-slash } & \text { CM-tree } & \text { CM-branch } & \text { DEF } & \text { COM } & \text { CM-cutlass }\end{array}$

'The man slashed the tree branch (with a cutlass).' (clip 3)

b. *Os’oshẽ̌n ótế.

$\begin{array}{lll}\text { *o-sí } & \text { o-sh } \check{\tilde{\varepsilon}} \quad \text { ní } & \text { ó-tẽ́ } \\ \text { CM-tree } & \text { CM-branch DEF } & \text { SM-slash } \\ \text { *'The branch slashed.' } & \end{array}$

3.3.2 Bhui 'cut'. This verb is used to describe most cutting events involving a sharp instrument such as a pair of scissors or a knife and like tế 'slash', it denotes activities performed by an agent as illustrated by the sentences in (14). This verb is used to describe cutting events involving a fine and precise cut such as scenarios in which clothes designers cut textiles to make garments as well as the process of chopping vegetables for the preparation of sauce. It is also used in contexts where body parts are severed or are incised into, such as bhui (k)ıtskpu' 'behead' (lit. 'cut head') and bhui (b) Únyínyi 'circumcise' (lit. 'cut penis') expressing the cultural practice of the initiation of a male child. The equivalents of these expressions are the same as in Ewe (see Table1 below).

(14) a. Ányínúvōēń ébhui károtīním trabha.

$\begin{array}{lllll}\text { á-nyínóvō̄ ní } & \text { é-bhui károtī } & \text { ní } & \text { kımı } & \text { tıa-bha } \\ \text { CM-boy DEF } & \text { SM-cut carrot } & \text { DEF } & \text { inside } & \text { AM-two } \\ \text { 'The boy cut the carrot into two.' (clip 9) } & & \end{array}$

b. Ányínúvōēń ébhui kishǐń nı sâ.

á-nyínóvō̄ ní é-bhui ki-shǐ ní nı sâ
CM-boy DEF SM-cut CM-stick DEF COM saw
'The boy cut the stick with a saw.' (clip15)

(14a) and (14b) were given by consultants as descriptions of events in which a carrot was cut into two (clip 9) and in which a stick was sawn in two (clip 15). Although a sharp instrument is the default instrument, bhui 'cut' was also used to describe an event in which a hammer was used to sever a piece of cloth (clip 23) or in which someone used a hand (in a karate way) to sever a rope (clip 61) and the effects produced by these actions were like those of a sharp instrument. The sentences in (15a) and (15b) were given as descriptions of these events:

(15) a. Ányínúvōēń ébhui kepútakpáním̄ tıabha nı hámā.

$\begin{array}{llllllll}\text { á-nyínóvōe ní } & \text { é-bhui ke-pútakpá } & \text { ní } & \text { kımı } & \text { tıa-bha } & \text { nı } & \text { háma } \\ \text { CM-boy } & \text { DEF } & \text { SM-cut CM-piece.of.cloth } & \text { DEF } & \text { inside } & \text { AM-two } & \text { COM } & \text { hammer } \\ \text { 'The boy cut the piece of cloth into two with a hammer.' } & & & \end{array}$


b. Ányínơvōēń ébhui ohuiń n'ahot.

$\begin{array}{lllll}\text { á-nyínóvōê ní } & \text { é-bhui o-hui } & \text { ní } & \text { nı } & \text { a-həı } \\ \text { CM-boy DEF } & \text { SM-cut CM-rope } & \text { DEF } & \text { with } & \text { CM-hand } \\ \text { 'The boy cut the rope with his hand.' } & & & \end{array}$

It is interesting to note that the verb bhui 'cut' occurs in intransitive constructions in restricted contexts such as cuts in the body as in (16a). The equivalent of the verb bhui 'cut' in the contact language Ewe, namely, tso 'cut' cannot be used intransitively to describe a situation such as the one represented in (16a). It has to be expressed in a transitive construction as in (16c). However, in Ga the equivalent 'cut' verb fo can also be used intransitively to express a situation such as the one represented in (16a), as shown in (16b) involving a different body part.

(16) a. Y'ítsrún íbhui.

$\begin{array}{lll}\text { yí } \quad \text { kı-tsrǐ ní } & \text { kí-bhui } \\ \text { 3SG.IND CM-toeDEF } & \text { SM-cut }\end{array}$

'His toe got cut.' (Lit.: 'His toe cut.')

b. E-wao fo

$[\mathrm{Ga}]$

3SG-finger cut

'She cut her finger' (cf. Kropp Dakubu 2009)

c. Kofi tso afo

[Ewe]

Kofi cut foot

'Kofi cut (his) toe.', i.e., 'Kofi's toe got cut.' Or 'Kofi hurt his toe.'

d. Kofí ébhui y'ítsrǐ.
Kofí é-bhui yí
kl-tsrǐ
Kofí SM-cut 3SG.IND CM-toe
'Kofi cut his toe' or 'Kofi hurt his toe.'

The situation represented in (16a) can be presented in alternative ways in Tafi: the possessor of the body-part can be expressed as the subject in the clause and the possessed body-part occurs as the object as shown in (16d). What these examples show is that the bhui 'cut' verb can occur in an intransitive clause as well as in two-place constructions. Recall that CUT verbs are not expected to behave syntactically like this.

Similarly, if the cut was caused by an instrument, the instrument can also be introduced as the subject of the sentence. In such a case, either the possessor together with the possessed body-part or only the possessed body-part will occur as the object of the sentence as in (17a). Additionally, the instrument can be introduced through a take-SVC as in (17b) or in a comitative prepositional phrase comparable to the examples in (15). 
(17) a. Kápamín 'ébhui y’ítsrǐ.

ká-pamí ní ké-bhui yí kı-tsrǐ

CM-cutlass DEF SM-cut 3SG.IND CM-toe

'The cutlass cut his toe.'

b. Áyíks kápamín ébhui y’ítsrǐ.
á-yíko ká-pamí ní
é-bhui yí
kı-tsrǐ
3SG-take CM-cutlass DEF SM-cut 3SG.IND CM-toe
'He used the cutlass to cut his toe.'

Other intransitive uses of the verb involve event composition, that is, they lead to different readings and these will be discussed in Section 5 in the context of the extended meanings of the Tafi CUT verb bhui.

3.2.3 Yá 'cut'. Yá 'cut' is another CUT verb used to describe cuts made on the human body. It involves the use of sharp instruments such as knives and razor blades. For instance, in the 'cut \& break' video elicitation, this verb was used to describe a woman cutting her finger with a knife (clip 18).

(18) Adzīń éébhui okútú kılí thěń áyá y’íwě.

\begin{tabular}{|c|c|c|c|c|}
\hline a-dzì & ní & é-é-bhui & o-kútú & l-ȟ̌ \\
\hline CM-woman & DEF & SM-PRSPROG-cut & CM-orange CONJ & CM-knife \\
\hline ní á-yá & $y^{\prime}$ & kl-wě & & \\
\hline DEF SM-cut & & G.IND CM-finger & & \\
\hline
\end{tabular}

'The woman is cutting an orange and the knife cut her finger.'

The verb yá 'cut' can also be used in certain contexts to mean 'bite-off/break-off a piece of something' and 'branch-off (a road)' as illustrated in (19).

(19) a. Ámā áyá kekupín.

$\begin{array}{llll}\text { Ámā } & \text { á-yá } & \text { ke-kupí } & \text { nı } \\ \text { Ama } & \text { CM-bite.off } & \text { CM-yam.slice } & \text { DEF }\end{array}$

'Ama bit off a piece of the yam slice.'

b. Áyá ága kıjaním.
á-yá
á-ga
kt-na
ní kımı
3SG-branch.off SM-walk CM-right DEF inside
'S/He branched off to the right.'

It can be said that Tafi has three CUT verbs: a highly agentive one tế 'slash' which does not participate in the transitive-intransitive alternation; an agentive one bhui 'cut' and slightly specific and low transitive yá 'cut'. The reason the last two verbs have intransitive uses despite lexicalizing instruments is that they are not as high in transitivity as the marked highly transitive tế. They are used in intransitive constructions when the separation event they characterize does not require an 
instrument for its realization. There is a general versus specific relation between bhui and yá where the situations represented by yá pre-empt the use of bhui. For Tafi and other Kwa languages, the structure of the domain and the interactions between the verbs in it can explain the intransitive use of CUT verbs in addition to the lexical semantics and the separation event type that is being described.

\section{Semantic extensions of bhui 'cut' - areal or language specific?}

Cross-linguistically, it is observed that CUT and BREAK verbs tend to have physical uses where they describe prototypically separation caused in the material integrity of objects. However, they also tend to occur in collocations where the affected objects do not have material integrity as such. In such contexts, the expressions tend to have interpretations different from physical cutting and breaking (Spalek 2015). Thus in Spanish, for example, if the object of the CUT verb denotes a process or a state, it is interpreted as the cessation of that situation. The patterns of extensions seem to be areally distributed. For instance, in many European languages the verb 'break' collocates with law and it is interpreted as the transgression of a particular norm. In this section I explore such extensions and collocations of the agentive verb bhui 'cut' in Tafi and ask if similar extensions and collocations exist in the neighboring languages, Ewe, the dominant lingua franca among the Tafi, Akan and Ga. It emerges that some of the collocations and extensions are language specific while others seem to have an areal character.

In some uses of the verb bhui 'cut' in Tafi, some readings are generated which seem to be extensions from the use of the verb to express separation in the material integrity of an object.

One of the contexts which triggers an extended reading of the verb bhui 'cut' is when its object is a human settlement as in the expression in (20a) or a road or path as in (20b).

(20) a. Bhui kóxwí/sma

bhui kóxwí/o-ma

cut village/CM-town

'set up a village/town'

b. Bhui kidzo

bhui ki-dzo

cut CM-road

'Cut a road (in the forest).'

Both expressions have an interpretation of create something. This interpretation comes about as a result of metonymy, where the way these things are created involve the cutting of vegetation. Thus the reading is motivated by cultural practice.

Interestingly, the expression in (20a) has an exact equivalent in Ewe with the same reading as shown in (21a). The Ewe equivalent of (20b) however has a very different interpretation, as shown in (21b). This suggests that (20b) is a Tafi specific encoding idiom, based on physical cutting of vegetation to create a path. The Ewe literal equivalent does not involve the literal cutting of vegetation to create something. It rather involves fictive or actual motion from one side of the road to another side, i.e., cross the road. The Inland dialect of Ewe uses a SLASH verb in collocation with 'road' to express cutting vegetation to create a path/road sense as in $d z a ́$ mó lit. 'slash a 
road'. This expression entails a specific manner of creating a road, i.e. by slashing vegetation with an instrument. Anlo dialect Ewe speakers use the more general expression de mó lit., 'remove road' to represent such a situation.

Ewe

(21) a. Tso kófé/ du

cut village/town

'set up a village/town'

b. Tso mó

cut road

'cross a road'

A usage of the verb bhui 'cut' in Tafi also has a 'cross' reading in a context which is also used in Ewe. Compare the expression in (22a) from Tafi with its Ewe counterpart in (22b).

(22) a. Yíks kıpotí obhui búvūním̄.

\section{yíko kı-potí o-bhui bú-vū ní kımı}

take CM-cloth 2SG-cut CM-house DEF inside

'Use a piece of cloth to cross/divide the room'

Ewe

(22) b. Ko avo tso xo-a me.

Take cloth cut room-DEF containing.region

'Use a piece of cloth to cross/divide the room.'

In Tafi as well as in Ewe, the 'cut' verb can be used with a complement involving a nominal glossed as 'word/matter/case' to yield an interpretation of 'decide/judge a case', as shown in (23). As is evident from the examples in both languages, the nominal occurs as a dependent in a postpositional phrase that functions as the object.

(23) a. Bebhui 'ibúím kó 'álí.

be-bhui ki-búí kımı kó balí

3PL-cut CM-matter inside DAT 3PL

'The matter has been judged for them'

Ewe

(23)

$\begin{array}{llll}\text { b. Wó-tso nya me } & \text { ná } & \text { wó. } \\ \text { 3PL-cut matter containing region } & \text { DAT } & 3 P L\end{array}$

'The matter has been judged for them'

The verb bhui 'cut' can be used transitively to talk about the ending of a social relationship as in (24a). The Ewe verb tso does not have this ending of a social relationship interpretation. Ewe uses other verbs such as klã 'separate' or má 'divide' in such a context. However an Ewe counterpart of the Tafi sentence can be used in a situation where two people involved in a fight have been 
separated as illustrated in (24b). Thus the CUT verbs here are used to indicate the cessation of an existing state (24a) or an on-going process (24b).

(24) a. Bebhui 'al'ishí.

\section{be-bhui balí ki.shí}

3PL-cut 3PL middle

'They have been separated (i.e. people in a relationship).'

Ewe

(24) b. tso wó dome

cut 3PL middle

'go between them (to separate them) (i.e. people fighting).'

Table 1 summarizes some of the readings of the transitive uses of the 'cut' verb bhui in Tafi and its equivalents in Ewe and also in Ga and Akan. There is a lot of overlap pointing to areal patterns among the languages but there is also variation. All four languages have readings of the agentive CUT verb relating to beheading, or shortening something and weaning a child off the breast. There are some collocations that do not occur in Tafi but occur in the other three languages, namely, 'cut' = 'cross a road', and ' $\mathrm{N}$ cut Pro inside', i.e. 'excessive amounts of $\mathrm{N}$ '. There are some readings that are shared between Tafi and Ewe, the major lingua franca, but which do not occur in Akan and Ga. These are 'cut' = 'divide/partition a room' and 'cut' = 'judge/decide a case'. The converse of this also occurs where a collocation is present in Akan and Ga, but not in Tafi or Ewe. These are the 'cut a drink' and the 'cut a song' = 'compose a song collocations'. A more extensive study involving other languages especially the closely related Nyagbo and Avatime languages can help determine whether these patterns are Tafi specific, Ewe-Tafi specific or not. 


\begin{tabular}{|l|l|l|l|l|}
\hline Cut Verb readings & $\begin{array}{l}\text { Tafi } \\
\text { bhui }\end{array}$ & $\begin{array}{l}\text { Ewe } \\
\text { tso }\end{array}$ & $\begin{array}{l}\text { Ga } \\
\text { fo }\end{array}$ & $\begin{array}{l}\text { Akan } \\
\text { Twa }\end{array}$ \\
\hline Cut head, i.e. behead & Yes & Yes & Yes & Yes \\
\hline Cut breast (for offspring) = wean a child & Yes & Yes & Yes & Yes \\
\hline Cut $(\mathrm{N})$ top $=$ shorten & Yes & Yes & Yes & Yes \\
\hline Cut penis $=$ circumcise & Yes & Yes & Cut foreskin & Yes \\
\hline Cut $=$ establish a settlement & Yes & Yes & Yes & No \\
\hline Cut $=$ create path & Yes & No & No & Yes \\
\hline Cut $=$ create e.g picture & No & No & No & Yes \\
\hline Cut $=$ compose a song & No & No & Yes & Yes \\
\hline Cut a drink $=$ pour and consume & No & No & Yes & Yes \\
\hline N cut (Pro) inside $=$ excessive amounts of N & No & Yes & Yes & Yes \\
\hline Cut $=$ cross e.g road & No & Yes & Yes & Yes \\
\hline Cut $=$ divide/ partition a room & Yes & Yes & No & No \\
\hline Cut (a case) $=$ judge/ decide & Yes & Yes & No & No \\
\hline Cut $=$ end a social relationship & Yes & No & Yes & No \\
\hline Cut $=$ separate people fighting & No & Yes & No & No \\
\hline Cut = magical potion, bewitch & No & Yes & Yes & No \\
\hline
\end{tabular}

Table 1: Transitive uses of the CUT verbs in Tafi, Ewe, Ga and Akan

\subsection{Intransitive uses of the CUT verb bhui}

The intransitive use of the verb bhui also has various extended readings (see Table 2). In its intransitive use it can be used to express the end of an event or a period as in $(25 \mathrm{a}, \mathrm{b})$ or the loss of a property such as the slimy property of okra (25c). As is evident from $(26 a, b)$ the Ewe counterpart verb also has these interpretations, but not for the end of a period.

(25) a. Ikpã ní, llı 'unu ibhui.

\begin{tabular}{|c|c|c|}
\hline i-kpã ní & ılí & bu-nú i-bhui \\
\hline CM-life DEF & 3SG.IND & CM-limit SM-ct \\
\hline
\end{tabular}

b. Subhań ébhui.

\section{sobha ní é-bhui}

rain DEF 3 SG-cut

'The rainy season has come to an end.' Lit. 'The rain cut.'

c. otsıniń 'ún' óbhui.
o-tsıní ní bu-nú ó-bhui
CM-okro DEF CM-limit SM-cut
'The okra has lost its slimy nature.' 
Ewe

(26) a. Agbe-a nu tso.

life-DEF limit cut

'The life has ended.'

b. Fetri-a nu tso.

okro-DEF limit cut

'The okra has lost its slimy nature.'

Similarly, in both Ewe and Tafi the cut verbs can be used to talk about the cessation of the flow of a liquid (e.g. from a tap). Compare (27a) and (27b). The same reading is also available in Akan, but not in Ga. Also in Tafi and Ga, but not in Ewe and Akan, the intransitive instantiation of the agentive CUT verb is also used to talk about the drying up or the cessation of flow of a river, as illustrated in (28a) for the Tafi verb bhui. Such a structure can be combined in Tafi with another clause in a cause-result bi-clausal structure where the cause clause is headed by $k$ ó 'give; cause; let; make', as illustrated by the example in (28b).

\section{Tafi}

(27) a. Buní ní bhui.

$\begin{array}{lll}\text { bu-ní } & \text { ní } & \text { bhui } \\ \text { CM-water } & \text { DEF } & \text { cut }\end{array}$

'The water has ceased flowing (from the tap).'

Ewe

(27) b. tsi- $\varepsilon$ tso

water-DEF cut

'The water has ceased flowing (from the tap).'

Tafi

(28) a. Kenín 'ébhui.

ke-ní ní ke-bhui

CM-river DEF SM-cut

'The river has stopped flowing.' (Lit. the river has cut.)

b. Ekpéń ákó keníń ébhui.
e-kpé
ní
á-kó ke-ní
ní ké-bhui
CM-dry weather DEF SM-cause CM-river DEF SM-cut

'The dry weather caused the river to stop flowing.'

All the extended uses of the verb bhui 'cut' in Tafi (and its counterparts in the other languages) involving an intransitive structure that we have discussed so far have involved an alternation where the theme (Undergoer) is the only participant expressed in the clause. There is one specialized use of the verb in Tafi where the single participant expressed in the clause is the agent (Actor). The expression in (29) has been routinized for ending one's speech. 
(29) Ibhui.

\section{i-bhui}

1SG-cut

'I am done.'

The Ewe counterpart verb tso can also be used to express the ending of a speech, but it has to occur in a two-place construction. The implication of an Ewe utterance like (30) is that the speaker may have more to say but it is ended here now. Such an implication is not associated with the Tafi expression.

Ewe

(30) Me-tso-e

1SG-cut-3SG

'I cut it', i.e., 'I end it (=the speech)'

Table 2 provides an overview of the readings of intransitive uses of the CUT verbs in Tafi , Ewe, Ga and Akan.

\begin{tabular}{|l|l|l|l|l|}
\hline Readings & $\begin{array}{l}\text { Tafi } \\
\text { Bhui }\end{array}$ & $\begin{array}{l}\text { Ewe } \\
\text { tso }\end{array}$ & $\begin{array}{l}\text { Ga } \\
\text { fo }\end{array}$ & $\begin{array}{l}\text { Akan } \\
\text { Twa }\end{array}$ \\
\hline Cut = end of a period / season & Yes & Yes & Yes & transitive \\
\hline Spontaneous cut e.g. Rope & Yes & Yes & No & No \\
\hline Cut = stop flowing of liquid & Yes & Yes & No & Yes \\
\hline Cut = drying up of river & Yes & No & Yes & No \\
\hline Cut= stop of speech & Yes & Transitive & No & Yes \\
\hline Get cut e.g toe & Yes & No & Yes & Yes \\
\hline
\end{tabular}

Table 2: Intransitive uses of CUT verbs in Tafi, Ewe, Ga and Akan

The intransitive readings of the Tafi verb are not all available in any of the other languages. At most each of the other languages has three of the six uses identified for Tafi. Interestingly, the patterns of occurrence across the languages is not uniform. Thus the Tafi 'cut' verb bhui has some readings which can be found in the area such as the end of an event and the loss of a property. However there are some language-specific readings that cannot be traced to other languages such as the routinized expression for ending a speech. More investigation of these forms across languages in the area would reveal variation and the diversity of meanings of separation predicates.

\section{Conclusion}

I have discussed the syntax and semantics of separation verbs of cutting and breaking in Tafi. I have shown that the BREAK verbs conform to the hypothesis about the causative/inchoative alternation. I have also demonstrated that the hypothesis concerning the CUT verbs needs to be reexamined. Like Ameka and Essegbey (2007) found for Ewe, it is only a highly agentive verb tế 
'cut/slash' which cannot occur intransitively. The other CUT verbs bhui and yá have intransitive counterparts. Drawing on the proposed scale of agentivity for CUT and BREAK verbs by Ameka and Essegbey (2007), it is suggested that the agentive CUT verbs bhui and yá occur in intransitive constructions when the separation event being described does not require an instrument. Also, some of the intransitive uses involve situations in which the affected theme object does not have material integrity as such. Furthermore, I have explored the extended readings of the agentive CUT verb bhui in Tafi in terms of its use outside the physical domain into social relationships and to other events and compared these to the uses of equivalent agentive CUT verbs in Ewe, Ga and Akan. It became evident that some of the readings are shared only with Ewe, the dominant lingua franca of the Tafi, e.g. 'cut a case' = 'judge a case'. Others occur in the four languages, e.g. 'cut breast' = 'wean a child'. The distribution of these collocations and semantic patterns raises questions about the understanding of contact effects in the lexicon and grammar of Tafi, as well as in the Kwa language speaking area. This is an issue for further research.

\section{Abbreviations Used}

3

AM

ATR

CM

DEF

FUT

IND

$\mathrm{N}$
Third person

Agreement Marker

Advanced tongue root

Class Marker

Definiteness marker

Future marker

Independent pronoun

Noun

$\begin{array}{ll}\text { NEG } & \text { Negative } \\ \text { PL } & \text { Plural } \\ \text { PRSPROG } & \text { Present Progressive } \\ \text { PSTPROG } & \text { Past Progressive } \\ \text { Pro } & \text { Pronoun } \\ \text { SG } & \text { Singular } \\ \text { SM } & \text { Subject Marker }\end{array}$

NEG Negative

PRSPROG Present Progressive

Past Progressive

Singular

Subject Marker

\section{References}

Agyepong, Dorothy P. 2017. Cutting and breaking events in Akan. PhD thesis, University of Cape Town.

Ameka, Felix K. 2006. Grammars in contact in the Volta Basin (West Africa): On contact induced grammatical change in Likpe. In Aikhenvald, Alexandra Y. and Robert M. W. Dixon (eds.) Grammars in contact: A crosslinguistic typology, 114-142. Oxford University Press,.

Ameka, Felix K. and James Essegbey. 2007. Cut and break verbs in Ewe and the causative alternation construction. Cognitive Linguistics 18(2), 241-250.

Bobuafor, Mercy. 2013. A grammar of Tafi. Utrecht: LOT

Bobuafor, Mercy Lamptey 2009. Noun classes in Tafi. In: M. Leo Wetzels (ed). The linguistics of endangered languages: morphology and syntax. (LOT Occasional Papers). Utrecht: LOT. 267-307.

Bobuafor, Mercy Lamptey. 2008. Cut and Break verbs in Tafi. Paper presented at the 26th West African Languages Congress, University of Education, Winneba, Ghana, July 28 - August 3, 2008 . 
Bohnemeyer, Juergen. 2007. Morpholexical Transparency and argument structure of verbs of cutting and breaking. Cognitive Linguistics 18(2), 153-177.

Bohnemeyer, Juergen, Melissa Bowerman, and Penelope Brown. 2001. Cut and break clips. In Levinson, Stephen C., and N. J. Enfield (eds.), Field Manual 2001, Language and Cognition Group, Max Planck Institute for Psycholinguistics. Nijmegen: MPI, 90-96.

Brown, Penelope. 2007. She had just cut/broken off her head': Cutting and breaking verbs in Tzeltal. Cognitive Linguistics18(2). 319-330.

Dakubu, Mary Esther Kropp (ed.). 2009. Ga-English dictionary with English-Ga index. $2^{\text {nd }}$ ed. Accra: Black Mask.

Guerssel, Mohamed, Kenneth Hale, Mary Laughren, Beth Levin, and Josie White Eagle. 1985. A cross-linguistic study of transitivity alternations. In Eilfort, W. H., P. D. Kroeber, and K. L. Peterson (eds.). Papers from the Parasession on Causatives and Agentivity at the 21 st Regional Meeting. Chicago, IL: Chicago Linguistic Society, 43-63.

Hale Kenneth, and Samuel J. Keyser. 1986. Some Transitivity Alternations in English. (Lexicon Project Working Papers 10). Cambridge, MA: Centre for Cognitive Science, MIT Press.

Haspelmath, Martin. 1993. More on the typology of inchoative/causative verb alternations. In Comrie, Bernard, and Maria Polinsky (eds.), Causatives and Transitivity, 87-120 Amsterdam: Benjamins.

Heine, Bernd. 1968 Die verbreitung und gliederung der Togorestsprachen. Berlin: D. Reimer. Huttar, George L., James Essegbey, and Felix K. Ameka.2007. Gbe and other West African sources of Suriname creole semantic structures: Implications for creole genesis. Journal of Pidgin and Creole languages 22.(1).: 57-72.

Levin, Beth. 1993. English Verb Classes and Alternations. Chicago: University of Chicago Press.

Levin, Beth, and Malka Rappaport Hovav. 1995. Unaccusativity: At the Syntax-Lexical Semantics Interface. Cambridge, MA: MIT Press.

Levin, Beth, and Malka Rappaport Hovav. 2005. Argument realisation. Cambridge University Press.

Majid, Asifa, James S. Boster, and Melissa Bowerman. 2008. The cross-linguistic categorization of everyday events: A study of cutting and breaking. Cognition, 109, 235-250.

Majid, Asifa, Melissa Bowerman, Miriam van Staden, and James S. Boster. 2007. The semantic categories of cutting and breaking events: A cross-linguistic perspective. Cognitive Linguistics 18(2), 133-152.

Næss, Åshild. 2012. Cutting and breaking in Äiwoo: Event integration and the complexity of lexical expressions. Cognitive Linguistics 23, 2:395-420.

Pye, Clifton. 1994. Breaking concepts: Constraining predicate argument structure. Unpublished manuscript. Department of Linguistics, University of Kansas.

Ring, Andrew J. 1995. Lelemi tone. Papers from GILLBT'S seminar week, January 30-February 3 1995. Tamale, pp. 16-26. Tamale: GILLBT Press.

Schaefer, Ronald P. and Francis O. Egbokhare. 2012. Emai Separation Verbs and Telicity. In Michael R. Marlo et al. (eds.) Selected Proceedings of the 42nd Annual Conference on African Linguistics, 257-265. Somerville, MA: Cascadilla Proceedings Project. www.lingref.com, document \#2774.

Simons, Gary F. and Charles D. Fennig. 2017. Ethnologue: Languages of the World, Twentieth edition. Dallas, Texas: SIL International. Online version: http://www.ethnologue.com 
Spalek, Alexandra Anna. 2015. Spanish change of state verbs in composition with atypical theme arguments: Clarifying the meaning shifts. Lingua 157. 36-53.

Welmers, William E. 1973. African language structures. Berkeley: University of California Press.

Mercy Bobuafor

mercybobuafor@gmail.com
Submitted: 24 September 2015

Accepted: 4 December 2016

Revisions: 1 January 2018 